\title{
Tannin Acyl Hydrolase Production by Citrobacter sp. isolated from Tannin rich Environment, using Tamarindus indica seed powder
}

\author{
${ }^{1}$ WILSON PETER A.; ${ }^{2}$ ROJAN P. JOHN; ${ }^{1}$ PRAVEEN KUMAR; ${ }^{1}$ SABU THOMAS \\ ${ }^{1}$ Molecular Microbiology Department, Rajiv Gandhi Centre for Biotechnology, \\ Thycaud PO, Trivandrum-695 014, Kerala, India. \\ ${ }^{2}$ Institut national de la recherche scientifique, 490, rue de la Couronne, Québec (QC), G1K 9A9, Canada. \\ *Corresponding author: Mailing address: Molecular Microbiology Department, Rajiv Gandhi Centre for Biotechnology, Thycaud PO, \\ Trivandrum-695 014, Kerala, India.Fax: +91471 2348096; Email: cnrmko@yahoo.com.rojanpj@yahoo.co.in
}

\begin{abstract}
Bacterial isolate, Citrobacter sp., from tannery effluent loaded sites has proved as a potent producer of tannase. Production of tannase was compared in solid-state and submerged fermentation using tamarind seed as sole carbon source. Two times increase in tannase activity was seen in solid-state fermentation $(90 \mathrm{U})$ than submerged fermentation ( $50 \mathrm{U})$ at $48 \mathrm{~h}$ from $5 \mathrm{~g}$ substrate @ JASEM
\end{abstract}

Tannase (tannin acyl hydrolase, E.C. 3.1.1.20) is an inducible extracellular microbial enzyme. It catalyses the hydrolysis of ester and depside bonds in hydrolysable tannin such as tannic acid releasing glucose and gallic acid. The enzyme is found to be useful in many food and industrial applications like manufacture of instant tea, acron wine, coffeeflavoured soft drinks, clarification of beer and fruit juices. Gallic acid is mainly used as an important substrate for the synthesis of propyl gallate, which is widely used as a food antioxidant and trimethoprim, a pharmaceutical antibacterial agent (Mohapatra et al, 2007). Even though presence of tannase was reported in plants and animals, microorganisms like fungus and bacteria are used for the industrial production. Fungus like Aspergillus (Pinto et al, 2001; Sabu et al, 2005) and bacteria such as Bacillus (Mondal et al, 2000a; b), Lactobacillus (Ayed and Hamdi, 2002; Sabu et al, 2006) were proved as potent producer of tannase. Fermentation using agro-residue, especially solid-state fermentation (SSF) has various advantages like low capital investment, better product recovery and less water output (Rojan et al, 2005). According to Sabu et al. $(2005 ; 2006)$ agro residues are the best substrates for tannase production by bacteria or fungi. In the current study a bacterium Citrobacter sp. isolated from the nearby areas of tannery effluent loaded site was characterized by biochemical methods. Its capacity of tannase production was studied using synthetic and commercial medium containing agro-residues.

\section{MATERIALS AND METHODS}

Water and soil samples were collected from nearby area of tannery and microorganisms were enriched in LB broth. Screening was carried out by plating after serial dilution on M9 minimal medium agar containing $0.5 \%$, w. $\mathrm{v}^{-1}$ tannic acid as sole carbon source. Selected strains were characterized using standard biochemical tests by following Bergey's manual of determinative bacteriology (Bergey et al, 1923). Attempt was also made to amplify the $16 \mathrm{~S}$ rRNA gene for identification of selected strain. The primers used to amplify the gene are $16 \mathrm{~S} \mathrm{~F}$ 5'CCGAATTCGTCGACAACAGAGTTTGATCCT

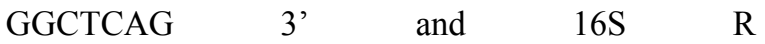
5'CCCGGGATCCAAGCTTACGGCTACCTTGTT ACGACTT 3'.

Tannase production was checked by the spectrophotometric and visual reading method (Osawa and Walsh, 1993) and utilization of tannic acid by plate assay. Selected colonies were subjected to tannase activity by allowing them to grow in LB broth containing $0.5 \%, \mathrm{w} \cdot \mathrm{v}^{-1}$ tannic acid. Tannase activity was estimated at an interval of $24 \mathrm{~h}$ after inoculation $\left(10^{9}\right.$ c.f.u. grown in LB broth) by the method of Sharma et al. (2000), for three days. Strain having highest activity was selected for the solidstate and submerged fermentation using tamarind seed powder as carbon source. Five gram tamarind (Tamarindus indica) seed powder was used in both cases. Submerged fermentation was done in $250 \mathrm{ml}$ Erlenmeyer flask containing $97 \mathrm{ml}$ distilled water and $3 \mathrm{ml}$ mineral salt solution $\left(\mathrm{NH}_{4} \mathrm{NO}_{3}: \mathrm{MgSO}_{4} \cdot 7 \mathrm{H}_{2} \mathrm{O}: \mathrm{NaCl}=5: 1: 1\right)$. The tamarind seed powder moistened with mineral solution and distilled water $\left(70 \%\right.$, w. $\mathrm{w}^{-1}$ moisture) was used as $\mathrm{SSF}$ medium. After inoculation $\mathrm{SmF}$ was carried out at $30^{\circ} \mathrm{C}$ at $180 \mathrm{rpm}$ in an orbital shaker and the SSF flasks were incubated in an environmental chamber at same temperature.

\section{RESULTS AND DISCUSSION}

Six morphologically different isolates obtained from the tannin rich environment were tested for the degradation of tannic acid. Swam plate assay proved the degradation ability of the test strain by forming clear zone in oxidized tannic acid (brown colour) (Fig.1). 
Table 1 Important biochemical test results for the identification of bacterial isolate

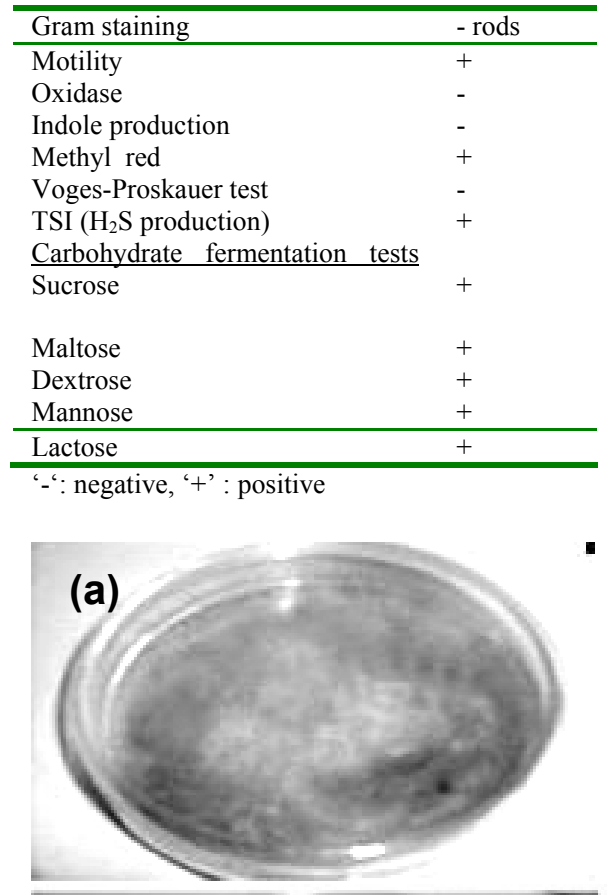

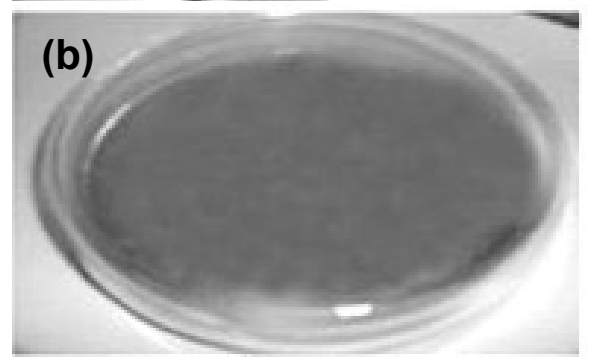

Fig. 1 Swarm plate assay showing utilization of tannic acid as sole carbon source was confirmed by chemo taxis. Initially the whole plate was brown in colour. After 18-24 hrs, chemo taxis was detected by movement of cells from the centre (zone of carbon depletion) of the plate towards periphery (zone of carbon sufficiency). As the bacteria moved from the centre to periphery, a clear zone was formed in the centre, indicating degradative ability of isolates. The plates acquired a dark brown color (presumably because of the oxidation of tannic acid). a. Citrobacter sp. (Test strain), b. Control

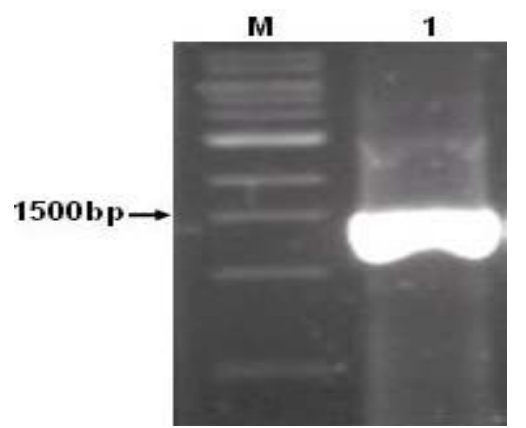

Fig. 2 16S rRNA gene amplification. Ethidium bromide stained agarose $(0.8 \%)$ gel electrophoresis. Lane $\mathrm{M}-1 \mathrm{~Kb}$ marker, lane 1 Citrobacter sp.
The efficient tannic acid degrading isolate was identified as Citrobacter sp. by biochemical tests (Table 1). Its 16S rRNA gene was amplified using $16 \mathrm{~S}$ universal primers (Fig.2) and the sequence analysis proved the generic nature of selected isolate to Citrobacter.

After alkalinization and exposure to atmosphere for 1 $\mathrm{h}$ the strain producing tannase change the green colour of the medium to brown and give an absorbance of 0.753 at a wavelength of $440 \mathrm{~nm}$. The colour change is due to the hydrolysis of methyl gallate by tannase and release of the free gallic acid. Vaquero et al. (2004) considered absorbance values above 0.5 as positive result for tannase activity. In the present study identical results were obtained by using the spectrophotometric and the visual reading method, in order to identify the tannase producing bacterial strains. Tannase production of Citrobacter sp. was tested by growing it in LB broth containing $0.5 \% \mathrm{~W} \mathrm{v}^{-1}$ tannic acid and there was $0.4 \mathrm{U}^{-\mathrm{ml}^{-1}}$ activity observed after $24 \mathrm{~h}$ and there was a decline in the activity beyond this period. As to reduce the cost of production, an agro-industrial residue tamarind seed powder was used as carbon source as it is rich in tannins. Here a rising trend in the enzyme production was observed upto $48 \mathrm{~h}\left(0.5 \mathrm{U}_{\mathrm{ml}} \mathrm{m}^{-1}\right)$. Under SSF the production was greatly influenced and the maximum yield was observed at $48 \mathrm{~h}\left(18 \mathrm{U} . g d s^{-1}\right)$ corresponds to the $90 \mathrm{U} 5$ g.substrate ${ }^{-1}$. Current study supports the advantages of SSF over SmF, not only in the cost of production but also in the enzyme yield. There was a twofold increase in the enzyme yield in SSF than SmF under unoptimized conditions.

The current study on bacterial yield of tannase was comparable with the recent reports. Mohapatra et al. (2007) reported that the production of tannase, using immobilized cells, increased with increasing alginate concentration and reached a maximum enzyme yield of $0.56 \pm 0.03 \mathrm{U} . \mathrm{ml}^{-1}$ at $20 \mathrm{~g} . \mathrm{l}^{-1}$. According to them it was about 1.7 fold higher than that obtained by free cells. Sabu et al. (2006), reported a maximum tannase yield of $0.85 \mathrm{U} . g d s^{-1}$ in SSF using coffee husk, supplemented with $0.6 \%$ tannic acid and $50 \%$, w.v ${ }^{-1}$ moisture, inoculated with $1 \mathrm{ml}$ Lactobacillus sp. suspension and incubated at $33^{\circ} \mathrm{C}$ for $72 \mathrm{~h}$.

Even though Citrobacter sp. can be utilized agroindustrial residue effectively for tannase production, further studies are necessary to improve the production of tannase by optimizing different parameters of SSF and SmF and screening of more substrates for the economic production. It is also necessary to achieve complete understanding of the regulation, catalytic capacity, specificity and other aspects of optimization of this industrial enzyme production at large scale. 
Acknowledgement: The authors are thankful to Prof. M. Radhakrishna Pillai, Director, RGCB for providing the facilities.

\section{REFERENCES}

Ayed L, Hamdi M (2002) Culture conditions of tannase production by Lactobacillus plantarum. Biotechnol Lett 24: 1763-1765

Bergey DH, Harrison FC, Breed RS, Hammer BW, Huntoon FM (1923) Bergey's Manual of Determinative Bacteriology, The Williams \& Wilkings Co., Baltimore.

Mohapatra PKD, Mondal KC, Pati BR (2007) Production of tannase by the immobilized cells of Bacillus licheniformis KBR6 in Ca-alginate beads. J Appl Microbiol 102: 1462-1467

Mondal KC, Banerjee R, Pati BR (2000a) Tannase production by Bacillus licheniformis. Biotechnol Lett 22, 767-769

Mondal KC, Pati BR (2000b) Studies on the extracellular tannase from newly isolated Bacillus licheniformis KBR 6. J Basic Microbiol 40: $223-232$

Osawa R, Walsh TP (1993) Visual reading method for detection of bacterial tannase. Appl Environ Microbiol 59: 1251-1252
Pinto GAS, Leite SGF, Terzi SC, Couri S (2001) Selection of tannase-producing Aspergillus niger strains. Braz J Microbiol 32: 24-26

Rojan PJ, Nampoothiri KM, Nair AS, Pandey A (2005) L (+) lactic acid production using Lactobacillus casei in solid-state fermentation. Biotechnol Lett 27: 1685-1688

Sabu A, Augur C, Swati C, Pandey A (2006) Tannase production by Lactobacillus sp. ASR-S1 under solid-state fermentation. Proc Biochem 41: 575580

Sabu A, Pandey A, Jaafar DM, Szakacs G (2005) Tamarind seed powder and Palm kernel cake: Two novel agro residues for the production of tannase under solid state fermentation by Aspergillus niger ATCC 16620. Bioresour Technol 96: 1223-1228

Sharma S, Bhat TK, Dawra RK (2000) A spectrophotometric method for assay of tannase using rhodanine. Anal Biochem 279: 85-89

Vaquero I, Marcobal Á, Muñoz R (2004) Tannase activity by lactic acid bacteria isolated from grape must and wine. International $\mathrm{J}$ Food Microbiol 96: 199-204 